\title{
NONLINEAR OPTICAL EFFECTS IN CRYSTALS OF LANGASITE FAMILY
}

\author{
N. Y. Ftomyn ${ }^{1}$ (D), Ya. I. Shopa ${ }^{2}$ (D) \\ ${ }^{1}$ Ivan Franko National University of Lviv, Faculty of Physics, \\ Department of General Physics, 19, Drahomanov St., Lviv, UA-79005, Ukraine, \\ ${ }^{2}$ Cardinal Stefan Wyszyński University in Warsaw, 5, Dewajtis St., 01-815 Warsaw, Poland, \\ e-mails: nazar.ftomyn@lnu.edu.ua, i.shopa@uksw.edu.pl \\ (Received 17 September 2020; in final form 18 November 2020; accepted 24 November 2020; \\ published online 18 December 2020)
}

A calculation technique based on the Dipole Electron Shifting model is applied to investigate the nonlinear optical properties of the crystals of langasite family. The $d_{11}$ component of nonlinear optical susceptibility tensors is determined for $\mathrm{La}_{3} \mathrm{Ga}_{5} \mathrm{SiO}_{14}, \mathrm{Ca}_{3} \mathrm{Ga}_{2} \mathrm{Ge}_{4} \mathrm{O}_{14}, \mathrm{La}_{3} \mathrm{Ga}_{5.5} \mathrm{Ta}_{0.5} \mathrm{O}_{14}$ $\mathrm{La}_{3} \mathrm{Ga}_{5.5} \mathrm{Nb}_{0.5} \mathrm{O}_{14}$ crystals. The results of the calculations are compared with the experimental ones, described in literature.

Key words: nonlinear optics, polarizabilities, langasite.

DOI: https://doi.org/10.30970/jps.24.4708

\section{INTRODUCTION}

In recent years, researchers have become increasingly interested in investigating new nonlinear optical (NLO) materials effective in the wide spectral region. The crystals of langasite family $\left(\mathrm{La}_{3} \mathrm{Ga}_{5} \mathrm{SiO}_{14}\right.$, $\mathrm{Ca}_{3} \mathrm{Ga}_{2} \mathrm{Ge}_{4} \mathrm{O}_{14}, \mathrm{La}_{3} \mathrm{Ga}_{5.5} \mathrm{Ta}_{0.5} \mathrm{O}_{14}, \mathrm{La}_{3} \mathrm{Ga}_{5.5} \mathrm{Nb}_{0.5} \mathrm{O}_{14}$, etc) are promising in the application in the midinfrared region (they are transparent up to $7 \mu \mathrm{m}$ ) [1]. They also attract great interest as systems with unique physical properties, e.g., dielectric, elastic, piezoelectric, etc $[2,3]$. The structural studies [4-6] have demonstrated that the crystalline systems under interest belong to the space symmetry group P321 $(Z=1)$. They are optically uniaxial, optically positive $\left(n_{e}>n_{o}\right.$, with $n_{e}$ and $n_{o}$ being respectively the extraordinary and ordinary refractive indices) and optically active (their gyration tensor $g_{i j}$ is diagonal, with two independent components $g_{11}=g_{22}$ and $\left.g_{33}\right)$. The optical activity of the some of these crystals are studied in [3, 7-11].

Nonlinear optical properties of crystals of the langasite family were widely investigated and reported in the works [1, 12-14]. The second harmonic generation effect is observed and $d_{11}$ coefficients were measured for $\mathrm{La}_{3} \mathrm{Ga}_{5} \mathrm{SiO}_{14}, \mathrm{Ca}_{3} \mathrm{Ga}_{2} \mathrm{Ge}_{4} \mathrm{O}_{14}, \mathrm{La}_{3} \mathrm{Ga}_{5.5} \mathrm{Ta}_{0.5} \mathrm{O}_{14}$, $\mathrm{La}_{3} \mathrm{Ga}_{5.5} \mathrm{Nb}_{0.5} \mathrm{O}_{14}$ e.g., in [12] $\left(d_{11}=1.7 \times 10^{-12} \mathrm{~m} / \mathrm{V}\right.$ for $\left.\mathrm{La}_{3} \mathrm{Ga}_{5} \mathrm{SiO}_{14}\right)$. It is necessary to note that there are no possibility to obtain the phase-matching conditions for $\mathrm{La}_{3} \mathrm{Ga}_{5} \mathrm{SiO}_{14}$ crystals in the range from 500 to $2500 \mathrm{~nm}$ [14] (in contrast, the directions of the phasematching were investigated and experimentally determined in [13] for $\mathrm{La}_{3} \mathrm{Ga}_{5.5} \mathrm{Ta}_{0.5} \mathrm{O}_{14}$ materials).

It is well known that for nonlinear crystals the polarization $\mathbf{P}$ can be expressed as [15]:

$$
P_{i}=\varepsilon_{0} \chi_{i j} E_{j}+2 d_{i j k} E_{j} E_{k}+\ldots+\text {. }
$$

Here $E_{j}$ denotes the $j$ th component of the electric field, $\chi_{i j}$ the linear susceptibility, $d_{i j k}$ the second-order nonlinear optical susceptibility, $\varepsilon_{0}$ the permittivity of free space.
The aim of our work is to calculate the NLO parameters (NLO susceptibility tensor components) of some crystals of the langasite family by using the method expressed in [17].

\section{CALCULATION METHOD}

It is well known that the calculation method based on the classical polarizability theory of optical activity [16] can be extended to determine the parameters of NLO effects (electrogyration, electro-optic effect and secondharmonic generation) [17]. There is the so-called DES (Dipole-dipole interaction electron-cloud shifting) model of calculations. The results of the applications of the DES available in literature [17-20] indicate the validity of the theoretical calculations based on this approach.

In the DES model, the virtual shift $\mathbf{x}$ of the electron cloud of the selected atom is directly proportional to its electronic polarizability $\alpha\left(x_{i}=\left(8 \varepsilon_{0} / e\right) \sum_{j} \alpha_{i j}^{\prime} E_{j}^{\text {Light }}\right.$, where $e$ is the electron charge, $\alpha^{\prime}=\alpha / 4 \pi \varepsilon_{0}$ the electronic polarizability volume, $\mathbf{E}^{\text {Light }}$ the field of light wave) [18]. As a result, the coefficients $d_{i j k}$ of NLO susceptibility tensor could be determined via relation [18]:

$$
\varepsilon_{i j}\left(E^{\text {Light }}\right)-\varepsilon_{i j}(0)=2 \sum_{k} d_{i j k} E_{k}^{\text {Light }} .
$$

Here $\varepsilon_{i j}$ denotes relative dielectric constants, $E_{k}^{\text {Light }}$ the $k$ th component of the field of light wave, and 0 refers to relative dielectric constants without electric field.

We have created our own software (the $\mathrm{C}++$ programming language was used) for calculating the electro-optic [22] and NLO susceptibility tensor components. In addition, our program was tested, in particular, for $\mathrm{SiO}_{2}$, D-mannitol $\left(\mathrm{C}_{6} \mathrm{H}_{14} \mathrm{O}_{6}\right)$, and $\mathrm{KH}_{2} \mathrm{PO}_{4}$ (KDP) crystals (we have obtained almost the same values of $d_{i j k}$ tensor components, as expressed in $[17,18])$. The errors of the calculations did not normally exceed $5 \%$ for the $d_{i j k}$. In contrast, there is the 
WinOPTACT software [21] for calculating the refractive and gyrotropic parameters of crystals based on the polarizability theory of optical activity [16].

\section{THE ELECTRONIC POLARIZABILITY VOLUMES AND RESULTS OF THE CALCULATION}

Let us consider the results of the calculations performed for $\mathrm{La}_{3} \mathrm{Ga}_{5} \mathrm{SiO}_{14}, \mathrm{Ca}_{3} \mathrm{Ga}_{2} \mathrm{Ge}_{4} \mathrm{O}_{14}$, $\mathrm{La}_{3} \mathrm{Ga}_{5.5} \mathrm{Ta}_{0.5} \mathrm{O}_{14}$ and $\mathrm{La}_{3} \mathrm{Ga}_{5.5} \mathrm{Nb}_{0.5} \mathrm{O}_{14}$ crystals, respectively. The values of electronic polarizability volumes have been determined for these materials in $[7,8,22]$ using the good correlation between the calculated and observed refractive indices and optical rotation in the direction of the optical axis. It is necessary to note that excellent agreement between the calculated and measured [7, 9] (the high-accuracy polarimetry method has been applied) optical rotation in the direction perpendicular to the optical axis for $\mathrm{Ca}_{3} \mathrm{Ga}_{2} \mathrm{Ge}_{4} \mathrm{O}_{14}$ and $\mathrm{La}_{3} \mathrm{Ga}_{5} \mathrm{SiO}_{14}$ crystals is reported.

The Lorentz-Lorenz equation [23] has been used to obtain the $\alpha^{\prime}$ for the wavelength of light $\lambda=$ $1064 \mathrm{~nm}$ (this wavelength of light is typically used in the second harmonic generation experiments). This method of determinatinf the wavelength dependence of electronic polarizability volumes has earlier been used for e.g., $\mathrm{SiO}_{2}$ [16], $\mathrm{La}_{3} \mathrm{Ga}_{5} \mathrm{SiO}_{14}, \mathrm{Ca}_{3} \mathrm{Ga}_{2} \mathrm{Ge}_{4} \mathrm{O}_{14}$, $\mathrm{La}_{3} \mathrm{Ga}_{5.5} \mathrm{Ta}_{0.5} \mathrm{O}_{14}[7,8,22]$. As a result the following values of $\alpha^{\prime}$ are estimated: $\alpha_{\mathrm{La}}^{\prime}=1.557 \AA^{3}$, $\alpha_{\mathrm{Ga}}^{\prime}=0.325 \AA^{3}, \alpha_{\mathrm{Si}}^{\prime}=0.561 \AA^{3}, \alpha_{\mathrm{O}}^{\prime}=1.725 \AA^{3}$ $\left(\mathrm{La}_{3} \mathrm{Ga}_{5} \mathrm{SiO}_{14}\right), \alpha_{\mathrm{Ca}}^{\prime}=1.121 \AA^{3}, \alpha_{\mathrm{Ga}}^{\prime}=0.262 \AA^{3}$, $\alpha_{\mathrm{Ge}}^{\prime}=0.240 \AA^{3}, \alpha_{\mathrm{O}}^{\prime}=1.633 \AA^{3},\left(\mathrm{Ca}_{3} \mathrm{Ga}_{2} \mathrm{Ge}_{4} \mathrm{O}_{14}\right)$, $\alpha_{\mathrm{La}}^{\prime}=1.996 \AA^{3}, \alpha_{\mathrm{Ga}}^{\prime}=0.412 \AA^{3}, \alpha_{\mathrm{Ta}}^{\prime}=0.902 \AA^{3}$, $\alpha_{\mathrm{O}}^{\prime}=1.731 \AA^{3}\left(\mathrm{La}_{3} \mathrm{Ga}_{5.5} \mathrm{Ta}_{0.5} \mathrm{O}_{14}\right), \alpha_{\mathrm{La}}^{\prime}=1.941 \AA^{3}$, $\alpha_{\mathrm{Ga}}^{\prime}=0.428 \AA^{3}, \alpha_{\mathrm{Nb}}^{\prime}=1.022 \AA^{3}, \alpha_{\mathrm{O}}^{\prime}=1.742 \AA^{3}$ $\left(\mathrm{La}_{3} \mathrm{Ga}_{5.5} \mathrm{Nb}_{0.5} \mathrm{O}_{14}\right)$, respectively. Because the considered systems belong to disordered materials, the polarizability volumes of the atoms occupying mixed $1 a, 2 d$ and $3 f$ Wickoff positions have been determined via the relations depending on site occupancy factors [46]: $0.5 \mathrm{Ga}+0.5 \mathrm{Si}\left(2 d, \mathrm{La}_{3} \mathrm{Ga}_{5} \mathrm{SiO}_{14}\right), 0.4 \mathrm{Ga}+0.6 \mathrm{Ge}$ and $0.53 \mathrm{Ga}+0.47 \mathrm{Ge}\left(1 a\right.$ and $\left.3 f, \mathrm{Ca}_{3} \mathrm{Ga}_{2} \mathrm{Ge}_{4} \mathrm{O}_{14}\right), 0.55 \mathrm{Ga}+$ $0.45 \mathrm{Ta} \quad\left(1 a \quad \mathrm{La}_{3} \mathrm{Ga}_{5.5} \mathrm{Ta}_{0.5} \mathrm{O}_{14}\right) \quad 0.48 \mathrm{Ga}+0.52 \mathrm{Nb} \quad(1 a$ $\left.\mathrm{La}_{3} \mathrm{Ga}_{5.5} \mathrm{Nb}_{0.5} \mathrm{O}_{14}\right)$.

Since the point symmetry group of the investigated crystals is 32 , the NLO susceptibility tensor can be written [15]:

$$
d_{i j}=\left(\begin{array}{cccccc}
d_{11} & -d_{11} & 0 & d_{14} & 0 & 0 \\
0 & 0 & 0 & 0 & -d_{14} & -d_{11} \\
0 & 0 & 0 & 0 & 0 & 0
\end{array}\right)
$$

Here contracted indices are used: $1=(11), 2=(22)$, $3=(33), 4=(23)=(32)$, etc. As a result, there are only two $d_{11}$ and $d_{14}$ nonzero independent components, respectively.
The calculated $d_{11}$ components for $\mathrm{La}_{3} \mathrm{Ga}_{5} \mathrm{SiO}_{14}$, $\mathrm{Ca}_{3} \mathrm{Ga}_{2} \mathrm{Ge}_{4} \mathrm{O}_{14}, \quad \mathrm{La}_{3} \mathrm{Ga}_{5.5} \mathrm{Ta}_{0.5} \mathrm{O}_{14}, \quad \mathrm{La}_{3} \mathrm{Ga}_{5.5} \mathrm{Nb}_{0.5} \mathrm{O}_{14}$ crystals are shown in Table 1.

As can be seen from the data in the Table 1, the results of the calculations are in excellent agreement with the experimental ones for $\mathrm{La}_{3} \mathrm{Ga}_{5} \mathrm{SiO}_{14}$ and $\mathrm{Ca}_{3} \mathrm{Ga}_{2} \mathrm{Ge}_{4} \mathrm{O}_{14}$ crystals, in contrast to $\mathrm{La}_{3} \mathrm{Ga}_{5.5} \mathrm{Ta}_{0.5} \mathrm{O}_{14}$ and $\mathrm{La}_{3} \mathrm{Ga}_{5.5} \mathrm{Nb}_{0.5} \mathrm{O}_{14}$ (the value of the calculated $d_{11}$ coefficients are approximately 4 times smaller). It may probably be explained by the application of the unsatisfactory sets of electronic polarizability volumes of the ions for these materials. In addition, the $\alpha^{\prime}$ of ions for $\mathrm{La}_{3} \mathrm{Ga}_{5} \mathrm{SiO}_{14}$ and $\mathrm{Ca}_{3} \mathrm{Ga}_{2} \mathrm{Ge}_{4} \mathrm{O}_{14}$ were determined using the experimental results of the optical activity in the direction parallel and perpendicular to the optical axis. As a result, the complete information about the gyrotropic properties of investigated materials is necessary for the correct calculation of the parameters of NLO effects in DES approach.

\begin{tabular}{lcc}
\hline \hline Crystal & $d_{11}, 10^{-12} \mathrm{~m} / \mathrm{V}$ & $\begin{array}{c}d_{11}, 10^{-12} \mathrm{~m} / \mathrm{V} \\
\text { Experimental results }\end{array}$ \\
\hline $\mathrm{La}_{3} \mathrm{Ga}_{5} \mathrm{SiO}_{14}$ & 1.48 & $1.7^{a}, 1.86^{b}$ \\
$\mathrm{Ca}_{3} \mathrm{Ga}_{2} \mathrm{Ge}_{4} \mathrm{O}_{14}$ & 0.82 & $0.9^{a}$ \\
$\mathrm{La}_{3} \mathrm{Ga}_{5.5} \mathrm{Ta}_{0.5} \mathrm{O}_{14}$ & 0.60 & $2.3^{a}, 2.4^{c}$ \\
$\mathrm{La}_{3} \mathrm{Ga}_{5.5} \mathrm{Nb}_{0.5} \mathrm{O}_{14}$ & 0.61 & $2.6^{a}$ \\
\hline$a[12], b[1], c[13]$ & & \\
\hline \hline
\end{tabular}

Table 1. Results of calculations

\section{CONCLUSIONS}

1. Components of the nonlinear optical susceptibility tensor of some crystals of the langasite family have been calculated using the dipole-dipole interaction model. Good correlation between the experimental (expressed in literature) and calculated parameters is reported for $\mathrm{La}_{3} \mathrm{Ga}_{5} \mathrm{SiO}_{14}$ and $\mathrm{Ca}_{3} \mathrm{Ga}_{2} \mathrm{Ge}_{4} \mathrm{O}_{14}$ crystals.

2. The values of the calculated $d_{11}$ coefficients are approximately four times smaller than the experimental ones for both $\mathrm{La}_{3} \mathrm{Ga}_{5.5} \mathrm{Ta}_{0.5} \mathrm{O}_{14}$ and $\mathrm{La}_{3} \mathrm{Ga}_{5.5} \mathrm{Nb}_{0.5} \mathrm{O}_{14}$ crystals. It may be explained by the application of the unsatisfactory sets of electronic polarizability volumes of the ions for these materials.

3. To obtain correct values of the nonlinear optical susceptibility, the magnitude of the electronic polarizabilities should be determined according to complete information about the optical activity of the investigated material. 
[1] H. Lan, F. Liang, Z. Lin, H. Yu, H. Zhang, J. Wang, Int. J. Opt. 2017, 1 (2017); https://doi.org/10.1155/20 $17 / 2980274$.

[2] A. Kaminskii, L. Aminov, V.Ermolaev et al., Physics and Spectroscopy of Laser Crystals (Nauka, Moscow, 1986).

[3] K. Kaldybaev, A. Konstantinova, Z. Perekalina, Gyrotropy of Uniaxial Absorbing Crystals (ISPIN, Moscow, 2000).

[4] B. V. Mill, A. A. Klimenkova, B. A. Maximov, V. N. Molchanov, D. Yu. Pushcharovsky, Crystallogr. Reps. 52, 785 (2007); https://doi.org/10.1134/S10637745070 50069.

[5] B. A. Maksimov et al., Crystallogr. Rep. 50, 751 (2005); https://doi.org/10.1134/1.2049391.

[6] G. M. Kuz'micheva, E. A. Tyunina, E. N. Domoroshchina, V.B. Rybakov, A.B.Dubovskii, Inorg. Mater. 41, 412 (2005); https://doi.org/10.1007/s10789-005-0 145-6.

[7] Ya. Shopa, N. Ftomyn, Opt. Appl. XLIII, 217 (2013); https://doi.org/10.5277/oa130202.

[8] Ya. Shopa, N. Ftomyn, Solid State Phenom. 200, 129 (2013); https://doi.org/10.4028/www.scientific.n et/SSP.200.129.

[9] M. Shopa, N. Ftomyn, Ya. Shopa, J. Opt. Soc. Am. 34, 943 (2017); https://doi.org/10.1364/JOSAA. 34.0 00943.

[10] A. F. Konstantinova, T. G. Golovina, B. V. Nabatov, A. P. Dudka, B. V. Mill, Crystallogr. Reps. 60, 907 (2015); https://doi.org/10.1134/S10637745150 60140.

[11] A. F. Konstantinova, T. G. Golovina, A. P. Dudka, Crystallogr. Reps. 63, 200 (2018); https:
//doi.org/10.1134/S1063774518020104.

[12] A.A. Kaminskyy, A. V. Butashin, I. A. Maslyanitsin V.D. Shigorin, Phys. Stat. Sol. (a). 112, K49 (1989); https://doi.org/10.1002/pssa.2211120172.

[13] E. Boursier et al., Optics Lett. 39, 4033 (2014); https: //doi.org/10.1364/0L.39.004033.

[14] R. Komatsu, T. Sugawara, S. Uda, Jpn. J. Appl. Phys. 36, 6159 (1997); https://doi.org/10.1143/JJAP.36. 6159.

[15] A. Yariv, P. Yeh, Optical Waves in Crystals. Propagation and Control of Laser Radiation (New York, Wiley, 1984).

[16] V. Devarajan, A. M. Glazer, Acta Cryst. A42, 560 (1986); https://doi.org/10.1107/S01087673860 98732.

[17] W. Kaminsky, A. M. Glazer, Z. Cristallogr. 212, 283 (1997); https://doi.org/10.1524/zkri.1997.212.4. 283.

[18] W. Kaminsky, A. J. Fitzmaurice, A. M. Glazer, J. Phys. D: Appl. Phys. 31, 767 (1998); https://doi.org/10.1 088/0022-3727/31/7/003.

[19] W. Kaminsky, Rep. Prog. Phys. 63, 1575 (2000); https: //doi.org/10.1088/0034-4885/63/10/201.

[20] W. Kaminsky, D. Responte, D. Daranciang J. Gallegos, B. Tran, T. Pham, Molecules 15, 554 (2010); https: //doi.org/10.3390/molecules 15010554 .

[21] A. M. Glazer, J. Appl. Cryst. 35, 652 (2002); https:// doi.org/10.1107/S0021889802013997.

[22] N. Ftomyn, Ya.Shopa, I. Sudak, Acta Phys. Pol. A 133, 933 (2018); https://doi.org/10.12693/APhysPo $1 \mathrm{~A} .133 .933$.

[23] M. Born, E. Wolf, Principles of Optics, 2nd ed. (Nauka, Moscow, 1970).

\title{
НЕЛІНІЙНО ОПТИЧНІ ЕФЕКТИ В КРИСТАЛАХ РОДИНИ ЛАНГАСИТІВ
}

\author{
Н. Є. Фтомин ${ }^{1}$, Я. І. Шопа ${ }^{2}$ \\ ${ }^{1}$ Львівсъкий націоналъний університет імені Івана Франка, фізичний факультет, кафедра загалъної фізики, \\ вул. Драгоманова 19, Лъвів, 79005, Украӥна \\ ${ }^{2}$ Університет кардинала Стефана Вишинсъкого, вул. Девайтіс 5, Варшава, 01-815, Полъща
}

Розрахунковий метод, що базується на DES-моделі (Dipole Electron Shifting), використано для дослідження нелінійно-оптичних властивостей кристалів родини лангаситів. У межах цього підходу також можна розраховувати параметри таких оптичних ефектів, як електрогірація, електрооптичний ефект тощо.

Визначено $d_{11}$-компоненту тензорів нелінійно-оптичної сприйнятливості кристалів $\mathrm{La}_{3} \mathrm{Ga}_{5} \mathrm{SiO}_{14}$ $\left(1.48 \times 10^{-12} \mathrm{~m} / \mathrm{B}\right), \mathrm{Ca}_{3} \mathrm{Ga}_{2} \mathrm{Ge}_{4} \mathrm{O}_{14}\left(0.82 \times 10^{-12} \mathrm{~m} / \mathrm{B}\right), \quad \mathrm{La}_{3} \mathrm{Ga}_{5.5} \mathrm{Ta}_{0.5} \mathrm{O}_{14}\left(0.60 \times 10^{-12} \mathrm{~m} / \mathrm{B}\right)$, $\mathrm{La}_{3} \mathrm{Ga}_{5.5} \mathrm{Nb}_{0.5} \mathrm{O}_{14}\left(0.61 \times 10^{-12} \mathrm{M} / \mathrm{B}\right)$ з використанням інформації про їхню кристалічну структуру та електронні поляризовності. Оскільки досліджувані об'єкти є розупорядкованими, електронні поляризовності йонів у кристалографічних позиціях $1 a, 2 d$ та $3 f$ розраховували згідно зі статистикою їх заповнення $\left(2 d: 0.5 \mathrm{Ga}+0.5 \mathrm{Si}-\mathrm{La}_{3} \mathrm{Ga}_{5} \mathrm{SiO}_{14}, 1 a: 0.4 \mathrm{Ga}+0.6 \mathrm{Ge}\right.$ та $3 f: 0.53 \mathrm{Ga}+0.47 \mathrm{Ge}-$ $\left.\mathrm{Ca}_{3} \mathrm{Ga}_{2} \mathrm{Ge}_{4} \mathrm{O}_{14}, 1 a: 0.55 \mathrm{Ga}+0.45 \mathrm{Ta}-\mathrm{La}_{3} \mathrm{Ga}_{5.5} \mathrm{Ta}_{0.5} \mathrm{O}_{14}, 1 a: 0.48 \mathrm{Ga}+0.52 \mathrm{Nb}-\mathrm{La}_{3} \mathrm{Ga}_{5.5} \mathrm{Nb}_{0.5} \mathrm{O}_{14}\right)$ для відповідних кристалів. Крім того, для обчислення величин поляризовностей для довжини хвилі 1064 нм використовували співвідношення Лорентц-Лоренца.

Визначені в цій роботі величини $d_{11}$ порівняли з експериментальними даними, наявними в літературі. Для кристалів $\mathrm{La}_{3} \mathrm{Ga}_{5} \mathrm{SiO}_{14}$ та $\mathrm{Ca}_{3} \mathrm{Ga}_{2} \mathrm{Ge}_{4} \mathrm{O}_{14}$ отримано достатньо добре узгодження між результатами розрахунків та експериментом. Натомість для $\mathrm{La}_{3} \mathrm{Ga}_{5.5} \mathrm{Ta}_{0.5} \mathrm{O}_{14}$ та $\mathrm{La}_{3} \mathrm{Ga}_{5.5} \mathrm{Nb}_{0.5} \mathrm{O}_{14}$ обчислені компоненти тензорів нелінійно-оптичної сприйнятливості суттєво відрізняються від літературних (розраховані значення $d_{11}$ приблизно в чотири рази менші). Цю особливість можна пояснити вибором неточних величин електронних поляризовностей для цих об'єктів, оскільки інформація про оптичну активність у напрямках, відмінних від оптичної осі, для цих кристалів відсутня.

Ключові слова: нелінійна оптика, поляризовності, лангасити. 